$<$ Contribution $>$ A study aimed at realizing manual tracking control system for reducing influence of individual difference, by Osamu SUENAGA \& Motozo IHARA.

\title{
個人差が及ぼす影響を低減する手動制御系 実現のための一研究*
}

\section{末長 修**, 井原素三**}

\begin{abstract}
A manual tracking control system is proposed by utilizing the design method of the model-following servo system, to aim at reducing the influence of the individual difference and keeping the control characteristics of the whole system constant independent of the human operator. We have proposed the manual tracking control system from the same points of view. But there are some problems on the realization of the plantmodel, the task load for the human operator, etc., when the previous system is applied to the practical man-machine system. So, in this study, the improvement plans are examined, and the availabilities of the plans are confirmed experimentally. As the improvement plans, the model is set up so as to describe the desired control characteristics of the whole system in advance, and the reference signal is displayed directly for the human operator, taking account of the practical use. Furthermore, it is assumed that the plant input is composed of the manipulated variable by the human operator and the designed control input, which makes the plant output agree with the output of the model. As a result, the problems are improved, the new proposed system gives the satisfactory result for reducing the difference of the controlled variable（the plant output） depended on the human operator. But, there still remain some problems on the sense of operation for the proposed system.
\end{abstract}

操作者によらず系の制御特性をほぼ一定に保ち，個人差が及ぼす影響の低減をめざした手動制御系 をモデル追従サーボ系設計手法をもとに構成した，以前に，同様の立場から手動制御系を提案したが， プラントモデルの実現，操作者に対する作業負担などいくつかの問題が残されていることが明らかに なった。そこで，本研究はこれらの問題に対して改善を図り，その有効性を実験的に確かめることを 目的とする．改善策として，モデルには手動制御系全体の所望の制御特性を表現し，操作者には実用 上の面から目標值を直接表示することにした。 さらに，プラントとモデルの両出力を一致させる制御 入力を操作者による操作量とともにプラント入力とする手動制御系を構成した。その結果, 先報にお ける諸問題は改善され，同時に操作者による制御量（プラント出力）の差異も低隇されることが確か められた。しかし，提案した系には設定条件により操作性が損なわれるなどの問題がいまだ残されて いる.

(キーワード：制御，トラッキング，個人差が及ほす影響の低隇)

\section{1. はじめに}

人間-機械系が実働した場合, 操作者により,また操

* 平成 3 年 6 月 17 日受付

** 静岡大学 工学部

Faculty of Eng., Shizuoka Univ.
作者が同一人であっても，身体の状態や周囲の環境な どにより，その動作は大きく変化する。このように人 間が介在する系は，操作者個人に依存する個人差によ り，たとえば制御特性の差異などといった影響を受け る.しかしながら，系の安全性などの面から，個人差 の存在のもとでも個人差が及ぼす人間-機械系への影 響が低減され，さらに系の制御特性が個人によらず所 


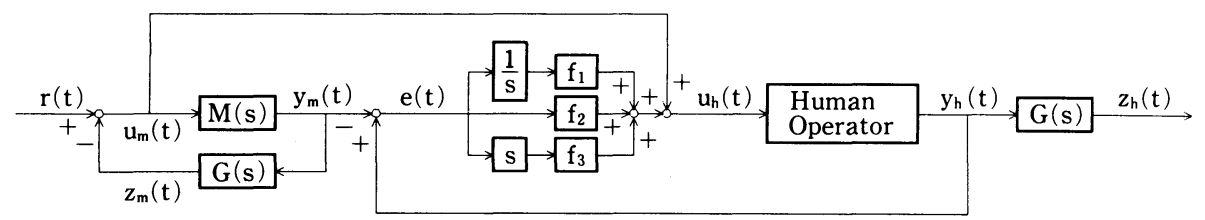

図 1 人間-機械系 (MF 系) の構成 ${ }^{1)}$

Fig. 1 Structure of man-machine system (Model-following system).

望の一定の特性を示すことが望ましい.

以上のような立場に立ち，筆者らは先報音において モデル追従サーボ系，すなわちプラント出力をあらか じめ設定したモデルの出力に一致させる系の設計手法 をもとに, 図 1 に示すような人間-機械系を構成し, 実 験室レベルでの測定ではあるが，系の制御特性が操作 者によらずほぼ一定となることを示した。しかし，先 報ではモデル $\mathrm{M}(\mathrm{s})$ に人間の平均的な制御特性のみを 表現し，プラント $\mathrm{G}(\mathrm{s})$ (図 1 右側)の特性変動などを 考慮していなかったため, プラントモデル $\mathrm{G}(\mathrm{s})$ (図 1 左側）の実現に関して実用上の問題が残されていた. すなわち，人間だけでなくプラントの特性をも表現す るモデルを設定する必要があった。また，このような モデルを設定したモデル追従サーボ系によれば，系全 体として所望の一定した特性が得られることも期待さ れる.さらに, 図1の系ではモデル出力 $\mathrm{y}_{\mathrm{m}}$ と操作量 $\mathrm{y}_{\mathrm{h}}$ との偏差 $\mathrm{e}$ を処理した信号とモデル入力 $\mathrm{u}_{\mathrm{m}}$ を加算し た $\mathrm{u}_{\mathrm{h}}$ を零化する操作を操作者に課していたため, 操作 の内容によっては過大な作業負担を操作者に与えると いう可能性も残されていた。

そこで本研究は，先報と同様にモデル追従サーボ系 設計手法をもとに個人差が及济す影響の低減をめざし た手動制御系を構成するが，その際，上述の問題に対 する改善を図り，その有効性を実験的に確かめること を目的とする。

改善策として, 第一の問題に対しては, 上述のよう にモデル追従サーボ系を構成する際，手動制御系全体 として所望の特性を表現するモデル (以後, 規範モデ ルと称する）を採用し，第二の問題に対しては，実用 性も考慮して, 目標值を人間に直接表示し, 規範モデ ル出力と個人差により異なるプラント出力との偏差を 零化する制御信号を，人間による操作量とともにプラ ント入力とするモデル追従サーボ系を構成することに する。

以上より, 本研究は古田の方法2)をもとに, 個人差が 及ぼす影響の低減をめざしたモデル追従手動制御系 (MFMTCS: Model-following Manual Tracking Control System）を構成する。

\section{2. 理 論}

\section{2-1.ＭFMTCS の記述}

MFMTCS の構成に際し, 本研究ではディジタル制 御を念頭におくため, 人間モデル（MFMTCSを記述 するための操作者モデル), プラントおよび規範モデル は，それぞれ以下に示す線形時不変離散時間系とする。 人間モデル $\left(m\right.$ 入力 $p_{h}$ 出力 $n_{h}$ 次系 $)$ :

$$
\begin{array}{ll}
\mathrm{x}_{\mathrm{h}}(\mathrm{k}+1) & =\mathrm{A}_{\mathrm{h}} \mathrm{x}_{\mathrm{h}}(\mathrm{k})+\mathrm{B}_{\mathrm{h}} \mathrm{r}(\mathrm{k}) \\
\mathrm{y}_{\mathrm{h}}(\mathrm{k}) & =\mathrm{C}_{\mathrm{h}} \mathrm{x}_{\mathrm{h}}(\mathrm{k}) \\
\text { プラント }\left(\mathrm{m}_{\mathrm{p}} \text { 入力 } \mathrm{p} \text { 出力 } \mathrm{n}_{\mathrm{p}} \text { 次系 }\right): \\
\mathrm{x}_{\mathrm{p}}(\mathrm{k}+1) & =\mathrm{A}_{\mathrm{p}} \mathrm{x}_{\mathrm{p}}(\mathrm{k})+\mathrm{B}_{\mathrm{p}} \mathrm{u}_{\mathrm{p}}(\mathrm{k})+\mathrm{w}(\mathrm{k}) \\
\mathrm{y}_{\mathrm{p}}(\mathrm{k}) \quad=\mathrm{C}_{\mathrm{p}} \mathrm{x}_{\mathrm{p}}(\mathrm{k})
\end{array}
$$

規範モデル $\left(\mathrm{m}\right.$ 入力 $\mathrm{p}$ 出力 $\mathrm{n}_{\mathrm{m}}$ 次系 $)$ :

$$
\mathrm{x}_{\mathrm{m}}(\mathrm{k}+1)=\mathrm{A}_{\mathrm{m}} \mathrm{x}_{\mathrm{m}}(\mathrm{k})+\mathrm{B}_{\mathrm{m}} \mathrm{r}(\mathrm{k})
$$$$
\mathrm{y}_{\mathrm{m}}(\mathrm{k}) \quad=\mathrm{C}_{\mathrm{m}} \mathrm{x}_{\mathrm{m}}(\mathrm{k})
$$

ただし, $\mathrm{x}(\mathrm{k}), \mathrm{u}(\mathrm{k}), \mathrm{y}(\mathrm{k})$ は, サンプリング時間間 隔 $\Delta \mathrm{t}$ でサンプリングされた $\mathrm{k}$ 時点でのそれぞれの状 態変数, 入力, 出力であり, $\mathrm{r}(\mathrm{k}), \mathrm{w}(\mathrm{k})$ はそれぞれ m次元目標值ベクトル, $\mathrm{n}_{\mathrm{p}}$ 次元外乱ベクトルである.ま た，A，B，C は係数行列である.

さらに, 目標值と外乱は次式を満足するものとする.

$$
\phi\left(\mathrm{q}^{-1}\right) \mathrm{r}(\mathrm{k})=\phi\left(\mathrm{q}^{-1}\right) \mathrm{w}(\mathrm{k})=0
$$

$$
\text { ただし }
$$

$$
\phi\left(\mathrm{q}^{-1}\right)=1+\rho_{1} \mathrm{q}^{-1}+\rho_{2} \mathrm{q}^{-2}+\cdots+\rho_{l} \mathrm{q}^{-\iota}
$$

$\mathrm{q}$ は $\mathrm{q}^{-1} \mathrm{r}(\mathrm{k})=\mathrm{r}(\mathrm{k}-1)$ と定義される時間推移作用 素である.

$$
\begin{array}{cc}
\text { ここでプラント }\left[\begin{array}{l}
\text { 式 }(2 . \mathrm{a})
\end{array}\right] \text { の係数行列 } \mathrm{B}_{\mathrm{p}} \text {, 入力 } \mathrm{u}_{\mathrm{p}} \text { を } \\
\mathrm{B}_{\mathrm{p}}=\left[\begin{array}{ll}
\mathrm{B}_{\mathrm{p} 1}, & \underbrace{\mathrm{B}_{\mathrm{p}}}_{\mathrm{p}_{\mathrm{h}}}
\end{array}\right] & \mathrm{m}_{\mathrm{p}}-\mathrm{p}_{\mathrm{h}} \\
\mathrm{u}_{\mathrm{p}}(\mathrm{k})=\left[\begin{array}{l}
\mathrm{y}_{\mathrm{h}}(\mathrm{k}) \\
\mathrm{u}_{\mathrm{c}}(\mathrm{k})
\end{array}\right] & (6 . \mathrm{b})
\end{array}
$$

とし, プラント出力 $\mathrm{y}_{\mathrm{p}}$ と規範モデル出力 $\mathrm{y}_{\mathrm{m}}$ との偏差 を

$$
\mathrm{e}(\mathrm{k}) \stackrel{\mathrm{d}}{=} \mathrm{y}_{\mathrm{p}}(\mathrm{k})-\mathrm{y}_{\mathrm{m}}(\mathrm{k})
$$

と定義すると, 本研究の目的は $\mathrm{k} \rightarrow \infty$ で $\mathrm{e}(\mathrm{k}) \rightarrow 0$ とす る制御入力 $\mathrm{u}_{\mathrm{c}}$ を設計することである. 
式(6)を式 (2.a) に代入し，式(1)〜(3)，(7)の両辺に $\phi$ $\left(\mathrm{q}^{-1}\right)$ をかけると，式(4)より $\mathrm{r}, \mathrm{w}$ が消去され，人間モ デル，プラントおよび規範モデルは，それぞれ以下の ように書き直される。

\section{人間モデル：}

$$
\begin{aligned}
\phi\left(\mathrm{q}^{-1}\right) \mathrm{x}_{\mathrm{h}}(\mathrm{k}+1)= & \mathrm{A}_{\mathrm{h}} \phi\left(\mathrm{q}^{-1}\right) \mathrm{x}_{\mathrm{h}}(\mathrm{k}) \\
\phi\left(\mathrm{q}^{-1}\right) \mathrm{y}_{\mathrm{h}}(\mathrm{k})= & \mathrm{C}_{\mathrm{h}} \phi\left(\mathrm{q}^{-1}\right) \mathrm{x}_{\mathrm{h}}(\mathrm{k}) \\
\text { プラント } & \\
\phi\left(\mathrm{q}^{-1}\right) \mathrm{x}_{\mathrm{p}}(\mathrm{k}+1)= & \mathrm{A}_{\mathrm{p}} \phi\left(\mathrm{q}^{-1}\right) \mathrm{x}_{\mathrm{p}}(\mathrm{k}) \\
& +\mathrm{B}_{\mathrm{p} 1} \phi\left(\mathrm{q}^{-1}\right) \mathrm{y}_{\mathrm{h}}(\mathrm{k}) \\
& +\mathrm{B}_{\mathrm{p} 2} \phi\left(\mathrm{q}^{-1}\right) \mathrm{u}_{\mathrm{c}}(\mathrm{k}) \\
= & \mathrm{A}_{\mathrm{p}} \phi\left(\mathrm{q}^{-1}\right) \mathrm{x}_{\mathrm{p}}(\mathrm{k})+\mathrm{B}_{\mathrm{p} 1} \mathrm{C}_{\mathrm{h}} \phi\left(\mathrm{q}^{-1}\right) \mathrm{x}_{\mathrm{h}}(\mathrm{k}) \\
+ & \mathrm{B}_{\mathrm{p} 2} \phi\left(\mathrm{q}^{-1}\right) \mathrm{u}_{\mathrm{c}}(\mathrm{k}) \\
\phi\left(\mathrm{q}^{-1}\right) \mathrm{y}_{\mathrm{p}}(\mathrm{k})= & \mathrm{C}_{\mathrm{p}} \phi\left(\mathrm{q}^{-1}\right) \mathrm{x}_{\mathrm{p}}(\mathrm{k})
\end{aligned}
$$

規範モデル：

$$
\begin{aligned}
& \phi\left(\mathrm{q}^{-1}\right) \mathrm{x}_{\mathrm{m}}(\mathrm{k}+1)=\mathrm{A}_{\mathrm{m}} \boldsymbol{\phi}\left(\mathrm{q}^{-1}\right) \mathrm{x}_{\mathrm{m}}(\mathrm{k}) \\
& \phi\left(\mathrm{q}^{-1}\right) \mathrm{y}_{\mathrm{m}}(\mathrm{k})=\mathrm{C}_{\mathrm{m}} \phi\left(\mathrm{q}^{-1}\right) \mathrm{x}_{\mathrm{m}}(\mathrm{k})
\end{aligned}
$$

偏差 $\mathrm{e}$ :

$$
\begin{gathered}
\phi\left(\mathrm{q}^{-1}\right) \mathrm{e}(\mathrm{k})=\boldsymbol{\phi}\left(\mathrm{q}^{-1}\right) \mathrm{y}_{\mathrm{p}}(\mathrm{k})-\boldsymbol{\phi}\left(\mathrm{q}^{-1}\right) \mathrm{y}_{\mathrm{m}}(\mathrm{k}) \\
=\mathrm{C}_{\mathrm{p}} \phi\left(\mathrm{q}^{-1}\right) \mathrm{x}_{\mathrm{p}}(\mathrm{k})-\mathrm{C}_{\mathrm{m}} \phi\left(\mathrm{q}^{-1}\right) \mathrm{x}_{\mathrm{m}}(\mathrm{k})
\end{gathered}
$$

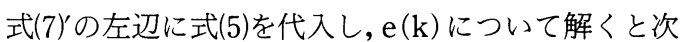
式を得る。

$$
\begin{aligned}
\mathrm{e}(\mathrm{k})= & \mathrm{C}_{\mathrm{p}} \phi\left(\mathrm{q}^{-1}\right) \mathrm{x}_{\mathrm{p}}(\mathrm{k})-\rho_{\mathrm{l}} \mathrm{e}(\mathrm{k}-1)-\rho_{2} \mathrm{e}(\mathrm{k}-2) \\
& \cdot-\cdots-\rho_{\mathrm{l}} \mathrm{e}(\mathrm{k}-l)-\mathrm{C}_{\mathrm{m}} \phi\left(\mathrm{q}^{-1}\right) \mathrm{x}_{\mathrm{m}}(\mathrm{k})
\end{aligned}
$$

以上の式(1) $\sim(3)^{\prime}$, 式(8)より, 拡張系

$$
\mathrm{x}_{\mathrm{a}}(\mathrm{k}+1)=\Phi \mathrm{x}_{\mathrm{a}}(\mathrm{k})+\Gamma \phi\left(\mathrm{q}^{-1}\right) \mathrm{u}_{\mathrm{c}}(\mathrm{k})
$$
を得る。ただし

$$
\begin{aligned}
& \mathrm{x}_{\mathrm{a}}(\mathrm{k})=\left[\phi\left(\mathrm{q}^{-1}\right) \mathrm{x}_{\mathrm{p}}(\mathrm{k})^{\mathrm{T}}, \mathrm{e}(\mathrm{k}-1)^{\mathrm{T}}, \mathrm{e}(\mathrm{k}-2)^{\mathrm{T}},\right. \\
& \left.\cdots, \mathrm{e}(\mathrm{k}-l)^{\mathrm{T}} \boldsymbol{\phi}\left(\mathrm{q}^{-1}\right) \mathrm{x}_{\mathrm{m}}(\mathrm{k})^{\mathrm{T}}, \boldsymbol{\phi}\left(\mathrm{q}^{-1}\right) \mathrm{x}_{\mathrm{h}}(\mathrm{k})^{\mathrm{T}}\right]^{\mathrm{T}} \\
& \stackrel{\mathrm{d}}{=}\left[\mathrm{x}_{1}(\mathrm{k})^{\mathrm{T}}: \mathrm{x}_{2}(\mathrm{k})^{\mathrm{T}}\right]^{\mathrm{T}}
\end{aligned}
$$

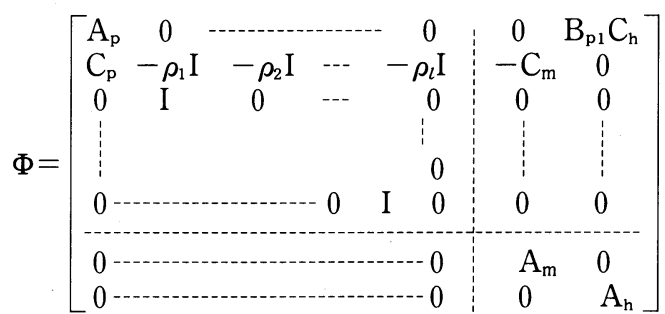$$
\stackrel{\mathrm{d}}{=}\left[\begin{array}{c:c}
\Phi_{1} & \Phi_{12} \\
\hdashline 0 & \Phi_{2}
\end{array}\right]
$$

$$
\begin{aligned}
& \Gamma=\left[\begin{array}{ll:ll}
\mathrm{B}_{\mathrm{p} 2}{ }^{\mathrm{T}}, & 0---0 & 0, & 0
\end{array}\right]^{\mathrm{T}} \\
& \stackrel{\mathrm{d}}{=}\left[\begin{array}{l:l}
\Gamma_{1}{ }^{\mathrm{T}} & 0
\end{array}\right]^{\mathrm{T}}
\end{aligned}
$$

ここで，Tは転置を表す。

式(9)の拡張系 $(\Phi, \Gamma)$ は可制御ではない.しかし, 本研究においては $\mathrm{x}_{\mathrm{a}}(\mathrm{k})$ のすべての状態変数を零化す
る必要はなく, $\mathrm{e}(\mathrm{k}-1), \mathrm{e}(\mathrm{k}-2), \cdots, \mathrm{e}(\mathrm{k}-l)$ を零 にすれば目的が達せられる。

\section{このためには, 離散型 2 次形式評価関数}

$$
\mathrm{J}=\sum_{\mathrm{k}=0}^{\infty}\left(\left\|\mathrm{x}_{\mathrm{a}}(\mathrm{k})\right\|_{\mathrm{Q}}{ }_{\mathrm{Q}}+\left\|\phi\left(\mathrm{q}^{-1}\right) \mathrm{u}_{\mathrm{c}}(\mathrm{k})\right\|_{\mathrm{R}}{ }_{\mathrm{R}}\right)
$$

を最小にする最適制御入力 $\phi\left(\mathrm{q}^{-1}\right) \mathrm{u}_{\mathrm{c}}$ を用いればよい. ただし，Qは半正定行列

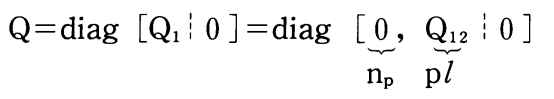

であり， Rは正定行列である.

このとき, 拡張系の最適制御入力 $\phi\left(\mathrm{q}^{-1}\right) \mathrm{u}_{\mathrm{c}}$ は次式に より与えられる。

$$
\phi\left(\mathrm{q}^{-1}\right) \mathrm{u}_{\mathrm{c}}(\mathrm{k})=-\left(\mathrm{R}+\Gamma^{\mathrm{T}} \mathrm{P} \Gamma\right)^{-1} \Gamma^{\mathrm{T}} \mathrm{P} \Phi \mathrm{x}_{\mathrm{a}}(\mathrm{k})
$$

ただし， $\mathrm{P}$ は離散型りカッチ方程式

$\mathrm{P}=\Phi^{\mathrm{T}} \mathrm{P} \Phi+\mathrm{Q}-\Phi^{\mathrm{T}} \mathrm{P} \Gamma\left(\mathrm{R}+\Gamma^{\mathrm{T}} \mathrm{P} \Gamma\right)^{-1} \Gamma^{\mathrm{T}} \mathrm{P} \Phi$ の正定対称解である.

$(\Phi, \Gamma)$ は可制御でないので, 式(14)を満たす $\mathrm{P} か ゙$ 存在 するかどうかはわからないが，Pを

$$
\left.\mathrm{P}=\left[\begin{array}{c:c}
\mathrm{P}_{1} & \mathrm{P}_{12} \\
\hdashline \mathrm{P}_{12} & \mathrm{P}_{2}
\end{array}\right]\right\} \mathrm{n}_{\mathrm{p}}+\mathrm{p} l
$$

と表し，式(10)を用いると，式(13)は

$$
\begin{gathered}
\phi\left(\mathrm{q}^{-1}\right) \mathrm{u}_{\mathrm{c}}(\mathrm{k})=-\left(\mathrm{R}+\Gamma_{1}{ }^{\mathrm{T}} \mathrm{P}_{1} \Gamma_{1}\right)^{-1} \times\left[\Gamma_{1}{ }^{\mathrm{T}} \mathrm{P}_{1}\right. \\
\left.\Phi_{1} \mathrm{x}_{1}(\mathrm{k})+\Gamma_{1}{ }^{\mathrm{T}}\left(\mathrm{P}_{1} \Phi_{12}+\mathrm{P}_{12} \Phi_{2}\right) \mathrm{x}_{2}(\mathrm{k})\right]
\end{gathered}
$$
となり, $\mathrm{P}_{1}, \mathrm{P}_{12}$ しか使われていない.ささに, $\mathrm{P}_{1}, \mathrm{P}_{12}$ は式(14)より，それぞれ以下のように与えられる。

$$
\begin{gathered}
\mathrm{P}_{1}=\Phi_{1}{ }^{\mathrm{T}} \mathrm{P}_{1} \Phi_{1}+\mathrm{Q}_{1}-\Phi_{1}{ }^{\mathrm{T}} \mathrm{P}_{1} \Gamma_{1}\left(\mathrm{R}+\Gamma_{1}{ }^{\mathrm{T}} \mathrm{P}_{1} \Gamma_{1}\right)^{-1} \\
\Gamma_{1}{ }^{\mathrm{T}} \mathrm{P}_{1} \Phi_{1} \\
\mathrm{P}_{12}=\Phi_{1}{ }^{\mathrm{T}} \mathrm{P}_{1} \Phi_{12}+\Phi_{1}{ }^{\mathrm{T}} \mathrm{P}_{12} \Phi_{2}-\Phi_{1}{ }^{\mathrm{T}} \mathrm{P}_{1} \Gamma_{1}\left(\mathrm{R}+\Gamma_{1}{ }^{\mathrm{T}}\right. \\
\left.\mathrm{P}_{1} \Gamma_{1}\right)^{-1} \Gamma_{1}{ }^{\mathrm{T}}\left(\mathrm{P}_{1} \Phi_{12}+\mathrm{P}_{12} \Phi_{2}\right)
\end{gathered}
$$

ここで， $\left(\Phi_{1}, \Gamma_{1}\right)$ は可制御であるので式 (17.a)を 満足する $\mathrm{P}_{1}$ は存在し, また式 (17.b) より $\mathrm{P}_{12}$ も与えら れることから， $\phi\left(\mathrm{q}^{-1}\right) \mathrm{u}_{\mathrm{c}}$ を決定することができる ${ }^{2)}$. 次に

$$
\mathrm{e}(\mathrm{k})=\phi\left(\mathrm{q}^{-1}\right) \boldsymbol{\xi}(\mathrm{k})
$$

なる $\boldsymbol{\xi}(\mathrm{k})$ ，すなわち

$$
\begin{gathered}
\boldsymbol{\xi}(\mathrm{k})=\mathrm{e}(\mathrm{k})-\rho_{1} \xi(\mathrm{k}-1)-\rho_{2} \xi(\mathrm{k}-2)- \\
\cdots-\rho_{l} \boldsymbol{\xi}(\mathrm{k}-l)
\end{gathered}
$$

を導入する. 式(10.a)，(18)を式(16)に代入し，両辺を $\phi$ $\left(\mathrm{q}^{-1}\right)$ で割ると，次式に示す制御入力 $\mathrm{u}_{\mathrm{c}}$ を得る。

$$
\begin{aligned}
\mathrm{u}_{\mathrm{c}}(\mathrm{k})= & \mathrm{F}_{1} \mathrm{x}_{\mathrm{p}}(\mathrm{k})+\mathrm{F}_{21} \xi(\mathrm{k}-1)+\cdots+\mathrm{F}_{2 l} \xi(\mathrm{k}-l) \\
& +\mathrm{F}_{3} \mathrm{x}_{\mathrm{m}}(\mathrm{k})+\mathrm{F}_{4} \mathrm{x}_{\mathrm{h}}(\mathrm{k})
\end{aligned}
$$

ただし

$\left[\mathrm{F}_{1}, \mathrm{~F}_{21}, \cdots, \mathrm{F}_{2 l}\right]=-\left(\mathrm{R}+\Gamma_{1}{ }^{\mathrm{T}} \mathrm{P}_{1} \Gamma_{1}\right)^{-1} \Gamma_{1}{ }^{\mathrm{T}} \mathrm{P}_{1} \Phi_{1}$

$$
\left[\mathrm{F}_{3}, \mathrm{~F}_{4}\right]=-\left(\mathrm{R}+\Gamma_{1}{ }^{\mathrm{T}} \mathrm{P}_{1} \Gamma_{1}\right)^{-1} \Gamma_{1}{ }^{\mathrm{T}}\left(\mathrm{P}_{1} \Phi_{12}+\mathrm{P}_{12} \Phi_{2}\right)
$$




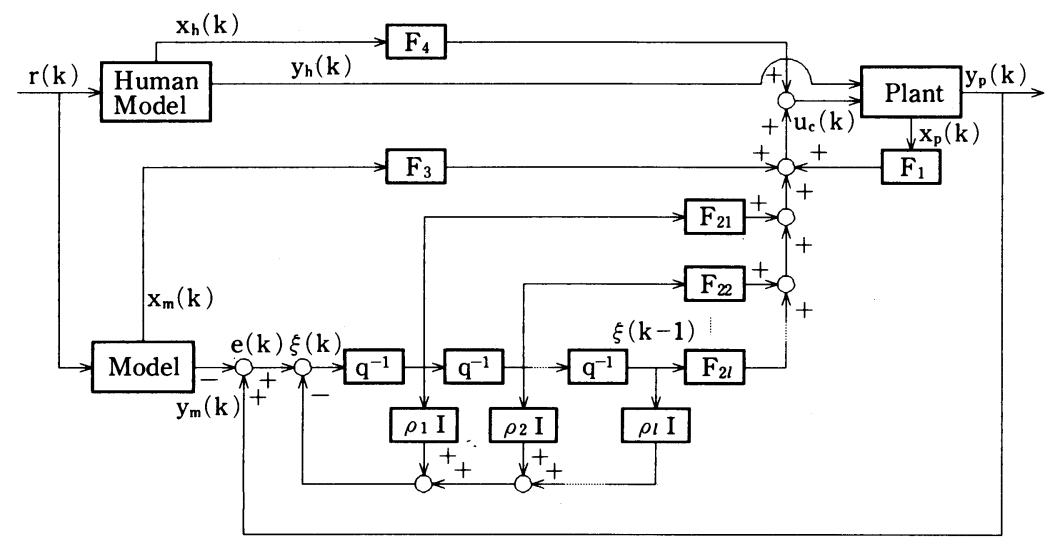

図 2 モデル追従手動制御系（MFMTCS）の構成

Fig. 2 Structure of model-following manual tracking control system.

以上より図 2 に示す MFMTCS が構成される。ここ で，実験の際，人間モデルは操作者に置き換えて測定 することになる。したがって，図 2 より操作者は目標 值に注視した制御が行えることになる。さらに，規範 モデルは手動制御系全体の特性を記述しているので, 規範モデルとプラントの両出力の偏差を零化する本 MFMTCS により，個人差による系の制御特性の差異 だけでなく,プラント特性の変動に対しても補償され ることになる。これらより, 前章で述べた問題が改善 され，個人差が及ぼす影響の低減をめざした一手動制 御系が構成されたものと考える。

\section{2-2. MFMTCS の実現}

前節において記述された MFMTCS を実現する.

ここで，式(20)で示したように制御入力 $\mathrm{u}_{\mathrm{c}}$ の決定には 操作中の操作者の人間モデルに対応する係数行列, 状 態変数を必要とするため, 本研究ではこれらの同定, 推定をオンラインで行う後述の適応オブザーバの導入 を考慮して, 人間モデルは以下に示すオブザーバ形 式)を採るものとし，また $\mathrm{A}_{\mathrm{h}}, \mathrm{B}_{\mathrm{h}}$ は時変とする. 同様 に，プラント，規範モデルをそれぞれ以下のように設 定する。

人間モデル $(1$ 入力 1 出力 2 次系) :

$$
\begin{aligned}
& \mathrm{A}_{\mathrm{h}}(\mathrm{k})=\left[\begin{array}{ll}
\mathrm{a}_{\mathrm{h} 1}(\mathrm{k}) & 1 \\
a_{\mathrm{h} 2}(\mathrm{k}) & 0
\end{array}\right], \mathrm{B}_{\mathrm{h}}(\mathrm{k})=\left[\begin{array}{l}
\mathrm{b}_{\mathrm{h} 1}(\mathrm{k}) \\
\mathrm{b}_{\mathrm{h} 2}(\mathrm{k})
\end{array}\right], \\
& \mathrm{C}_{\mathrm{h}}=[1,0]
\end{aligned}
$$

プラント ( 2 入力 1 出力 2 次系) :

$$
\begin{aligned}
& A_{p}=\left[\begin{array}{ll}
a_{p 1} & 1 \\
a_{p 2} & 0
\end{array}\right], B_{p}=\left[\begin{array}{ll}
b_{p 11} & b_{p 12} \\
b_{p 21} & b_{p 22}
\end{array}\right], \\
& C_{p}=[1,0]
\end{aligned}
$$

規範モデル $(1 \text { 入力 } 1 \text { 出力 } 1 \text { 次系 })^{*}$ :

$$
\mathrm{A}_{\mathrm{m}}=\mathrm{a}_{\mathrm{m}}, \mathrm{B}_{\mathrm{m}}=\mathrm{b}_{\mathrm{m}}, \mathrm{C}_{\mathrm{m}}=1
$$

さらに，目標值，外乱は一定值とする。したがって

$$
\phi\left(\mathrm{q}^{-1}\right)=1-\mathrm{q}^{-1} \quad(l=1)
$$
となる.

以上の設定より, 式(9)の拡張系の状態変数, 係数行 列（ベクトル）は以下のようになる。

$$
\begin{aligned}
& \mathrm{x}_{\mathrm{a}}(\mathrm{k})=\left[\phi\left(\mathrm{q}^{-1}\right) \mathrm{x}_{\mathrm{p} 1}(\mathrm{k}), \phi\left(\mathrm{q}^{-1}\right) \mathrm{x}_{\mathrm{p} 2}(\mathrm{k}), \mathrm{e}(\mathrm{k}-1)\right. \\
& \phi\left(\mathrm{q}^{-1}\right) \mathrm{x}_{\mathrm{m}}(\mathrm{k}), \phi\left(\mathrm{q}^{-1}\right) \mathrm{x}_{\mathrm{h} 1}(\mathrm{k}) \text {, } \\
& \left.\phi\left(\mathrm{q}^{-1}\right) \mathrm{x}_{\mathrm{h} 2}(\mathrm{k})\right]^{\mathrm{T}} \\
& \Phi=\left[\begin{array}{ccc:ccc}
\mathrm{a}_{\mathrm{p} 1} & 1 & 0 & 0 & \mathrm{~b}_{\mathrm{p} 11} & 0 \\
\mathrm{a}_{\mathrm{p} 2} & 0 & 0 & 0 & \mathrm{~b}_{\mathrm{p} 21} & 0 \\
1 & 0 & 1 & -1 & 0 & 0 \\
\hdashline 0 & -0 & \multicolumn{2}{c}{\mathrm{a}_{\mathrm{m}}} & 0 & 0 \\
\vdots & & 0 & \mathrm{a}_{\mathrm{h} 1}(\mathrm{k}) & 1 \\
0-- & 0 & 0 & \mathrm{a}_{\mathrm{h} 2}(\mathrm{k}) & 0
\end{array}\right] \\
& \Gamma=\left[b_{\mathrm{p} 12}, b_{\mathrm{p} 22}, 0: 0,0,0,\right]^{\mathrm{T}}
\end{aligned}
$$

\section{2-3. 適応オブザーバ3)}

前節において述べたように，1入力 1 出力系とした 操作者の測定可能な $\mathrm{y}_{\mathrm{h}}$ および $\mathrm{r}$ から，未知係数行列 $\mathrm{A}_{\mathrm{h}}, \mathrm{B}_{\mathrm{h}}$ を同定し,かつ同時に状態変数 $\mathrm{x}_{\mathrm{h}}$ の推定值 $\hat{\mathrm{x}}_{\mathrm{h}}$ を 推定する適応オブザーバを構成する.

本研究では文献 3）に基づき, 適応オブザーバの構造 を

$$
\begin{aligned}
& \hat{\mathrm{x}}_{\mathrm{h}}(\mathrm{k})=\Psi(\mathrm{k}) \hat{\Theta}(\mathrm{k}) \\
& \hat{\mathrm{y}}_{\mathrm{h}}(\mathrm{k})=\mathrm{z}(\mathrm{k})^{\mathrm{T}} \hat{\Theta}(\mathrm{k})
\end{aligned}
$$

とし, 適応同定則に離散形重みつき最小 2 乗適応同定 則

$$
\begin{aligned}
\hat{\Theta}(\mathrm{k}+1)= & \hat{\Theta}(\mathrm{k})-\frac{\Omega(\mathrm{k}-1) z(\mathrm{k}) \varepsilon(\mathrm{k})}{\lambda+\mathrm{z}(\mathrm{k})^{\mathrm{T}} \Omega(\mathrm{k}-1) z(\mathrm{k})}, \\
& 0<\lambda<1
\end{aligned}
$$




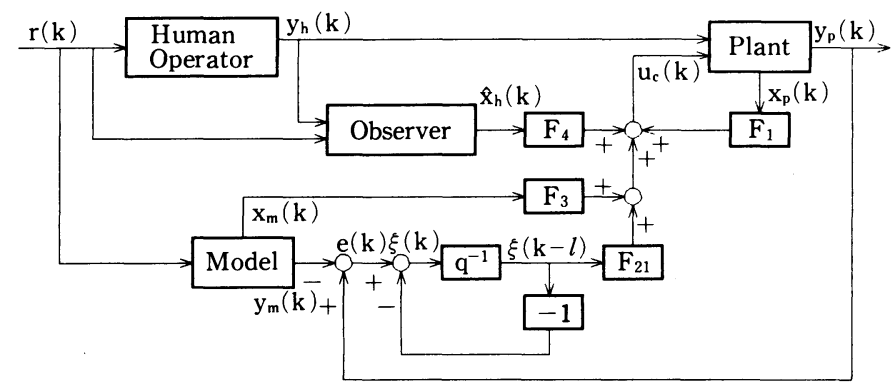

図 3 実験で用いるモデル追従手動制御系

Fig. 3 Model-following manual tracking control system for the experiment.

$$
\begin{aligned}
& \Omega(\mathrm{k}+1)=\frac{1}{\lambda}[\Omega(\mathrm{k})- \\
& \left.\frac{\Omega(\mathrm{k}) z(\mathrm{k}+1) z(\mathrm{k}+1)^{\mathrm{T}} \Omega(\mathrm{k})}{\lambda+z(\mathrm{k}+1)^{\mathrm{T}} \Omega(\mathrm{k}) z(\mathrm{k}+1)}\right], \quad \Omega(-1)>0 \\
& \varepsilon(\mathrm{k})=\hat{\mathrm{y}}_{\mathrm{h}}(\mathrm{k})-\mathrm{y}_{\mathrm{h}}(\mathrm{k})
\end{aligned}
$$

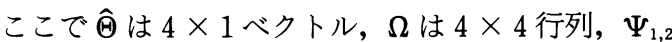
は $2 \times 2$ 行列, $z_{1,2}$ は $2 \times 1$ ベクトル, $\mathrm{I}_{2}$ は $2 \times 2$ 単位 行列であり，また $\mathrm{G}$ は以下に示す既知の漸近安定な $2 \times 2$ 行列, $\mathrm{g}$ はその要素べクトル $(2 \times 1)$ である.

$$
\mathrm{G}=\left[\begin{array}{l:l}
\mathrm{g} & 1 \\
& 0
\end{array}\right]
$$

以上より，本研究で構成する適応オブザーバを含め た MFMTCS は図 3 のようになる。

\section{3. 実験装置および実験方法}

実験システムは図 4 に示す追跡手動制御系である. 目標值 $\mathrm{r}(\mathrm{k})$ はランダムなステップ波であり,そのパワ ースペクトルは約 $0.1 \mathrm{~Hz}$ までほぼ平坦となる特性を 有する。表示装置にはパーソナルコンピュータ用ディ スプレイ (14 インチ)を用い, 目標值 $\mathrm{r}$ と制御量 $\mathrm{y}_{\mathrm{p}}(\mathrm{k})$ をそれぞれ上下 2 本の輝線の左右の動きとして表示す る.目標値の表示装置上での最大振幅は $23.4 \mathrm{~mm}$ であ る. 操作器は直径 $30 \mathrm{~mm}$ の回転つまみであり, それに ロータリエンコーダが連動している，回転つまみには 復元力は作用しない. プラントを比例要素 $(=1)$ と した場合のつまみの回転角度に対する表示装置上の輝 線の移動距離は $1.1 \mathrm{~mm} / \mathrm{deg}$ である。

プラント，規範モデルは，それぞれ以下のように設 定し,パーソナルコンピュータにより模擬する.

$$
\begin{aligned}
& \mathrm{A}_{\mathrm{p}}=\left[\begin{array}{rr}
1.30 & 1 \\
-0.36 & 0
\end{array}\right], \mathrm{B}_{\mathrm{p}}=\left[\begin{array}{rr}
0.10 & 0.20 \\
-0.05 & -0.10
\end{array}\right] \\
& \mathrm{a}_{\mathrm{m}}=0.90, \mathrm{~b}_{\mathrm{m}}=0.10 \\
& \text { ただし, サンプリング時間間隔 } \Delta \mathrm{t} \text { はコンピュータの }
\end{aligned}
$$

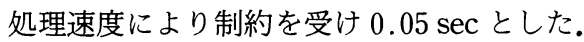

測定は MFMTCS の有効性を検討するため, 従来の 追跡手動制御系による（制御入力 $\mathrm{u}_{\mathrm{c}}$ を付加しない）実
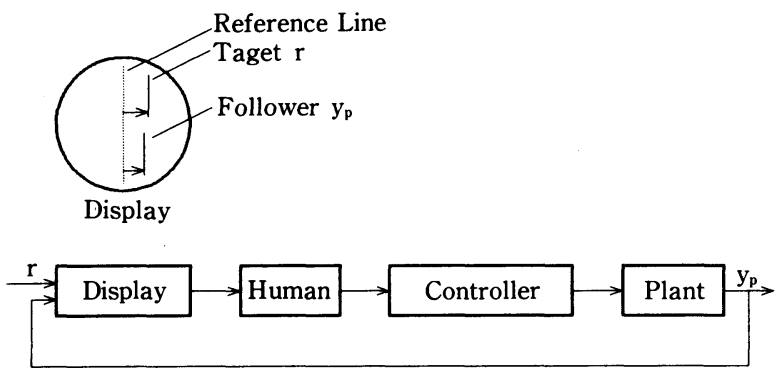

図 4 実験システム

Fig. 4 Experimental system. 


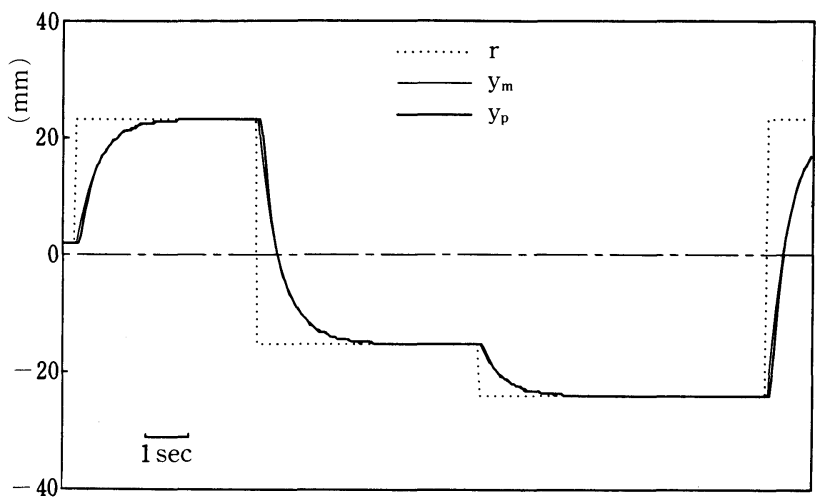

図 5 規範モデルと実験結果の比較（実験 II， 被験者 $\mathrm{M}-1$, 試行 10 回目)

Fig. 5 Comparison between reference model and experimental result (Ex. II, Sub. M-1, 10th trial).
験 I と MFMTCS による実験II, および試みとして式 (25)を満足しない一様ランダム信号を目標值とした MFMTCSによる実験IIIについて行う.

被験者は, この種の実験室内での手動制御に知識の ない健常な 20 歳代の男子学生 5 名である.ただし, 実 験IIIの被験者は男子 1 名とした。

測定は練習を行わず開始した. 試行回数は 10 回と し，全被験者，全試行について同一目標值を用いた。 1 試行時間は 120 秒, 1 試行ごとに約 10 秒の休憩時間

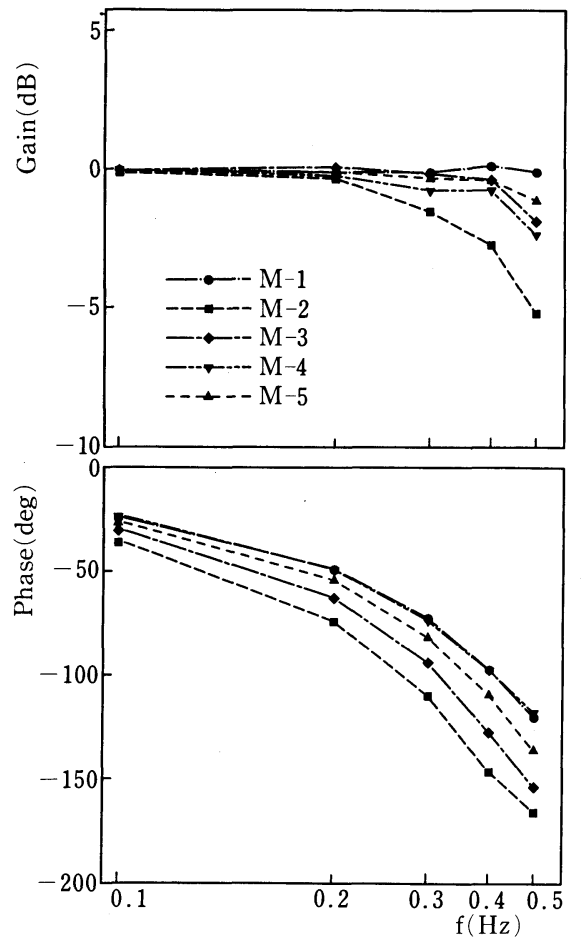

図 6 周波数応答特性（実験 I )

Fig. 6 Bode plots (Ex. I ).
を設け，その間に表示装置上における各試行の目標値 と制御量の誤差面積の推移を, 制御動作改善の動機づ けとして表示装置に提示した。測定にあたって，被験 者に対する指示は単に操作器の扱い方と追従に関する 基本的なものにとどめたまたた，“できるだけ目標值に 追従するように”と指示し，その制御動作の改善が詔 差面積の推移として提示されることも説明した。

また，式(11)の重み行列 $\mathrm{Q}_{1} ， \mathrm{R}$ は $\operatorname{diag} \mathrm{Q}_{1}=[0,0,2], \mathrm{R}=1$

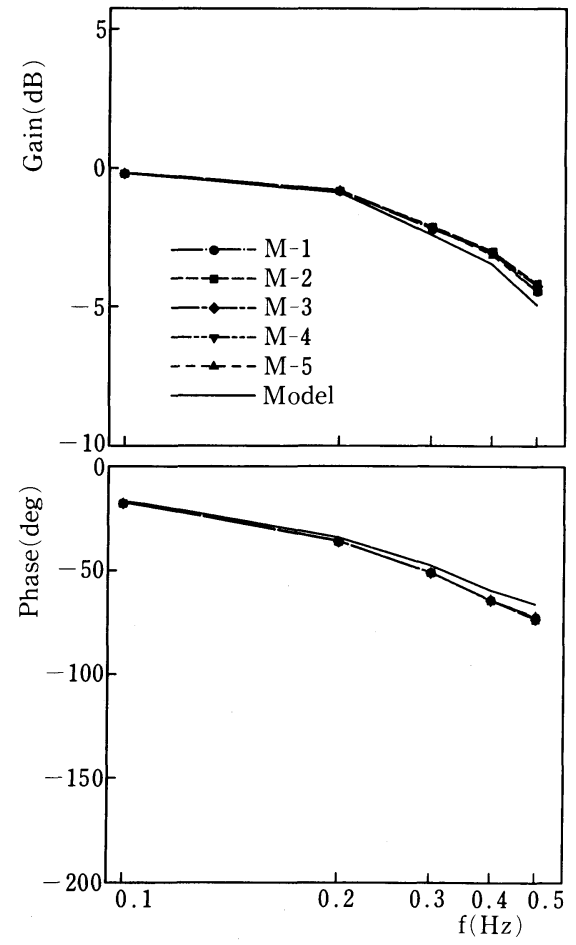

図 7 周波数応答特性（実験 II）

Fig. 7 Bode plots (Ex.II). 
と設定し，適応オブザーバのパラメータ，初期值は以 下のようにした。

$$
\begin{aligned}
& \lambda=0.1, G=\left[\begin{array}{cc}
0.02 & 1 \\
-0.0001 & 0
\end{array}\right] \\
& \hat{\Theta}(0)=\hat{\Theta}(1)=\left[\begin{array}{l}
-0.02 \\
0.0001 \\
0.1 \\
0.5
\end{array}\right],
\end{aligned}
$$$$
\Omega(0)=\frac{1}{\lambda} \Omega(-1)=\left[\begin{array}{rrrrr}
10 & & & & \\
& 10 & & \\
& & 10 & \\
& & & & 10
\end{array}\right]
$$

\section{4. 結果および考察}

本研究で構成した MFMTCSにより，被験者によら ずプラント出力 $\mathrm{y}_{\mathrm{p}}$ が規範モデル出力 $\mathrm{y}_{\mathrm{m}}$ と一致するか 否かを検討した。

まず，実験IIにおける $\mathrm{y}_{\mathrm{p}}$ と $\mathrm{y}_{\mathrm{m}}$ の比較を時間領域に ついて行った。両者の波形の一部を図 5 に示す。また， 実験 $\mathrm{I}, \mathrm{II}$ にいて，r に対する各被験者 $(\mathrm{M}-1 \sim 5)$ の $\mathrm{y}_{\mathrm{p}}$ の周波数応答特性を求めた結果を図 6,7 亿示 す。さらに，個人差による制御特性のバラツキを表す 指標として, 各周波数 $(0.1 \mathrm{~Hz}$ 間隔) におけるゲイ ン，位相の平均值および標準偏差を求めた。その結果 を表 1 に示す.

まず図 5 より， $\mathrm{y}_{\mathrm{p}}$ は $\mathrm{y}_{\mathrm{m}}$ によく追従していることが明 らかになった。また, 図 6, 7, 表 1 より, 実験 I で は特に高周波数領域で各被験者の制御特性のバラツキ がみられるが，実験IIでは各被験者ともその周波数特 性は互いによく一致し，また規範モデルのそれともほ ぼ一致することが確認された。また, 先報1において問 題となった人間のむだ時間の補償も本 MFMTCSに おいては解消されることも確かめられた。
表 1 周波数応答特性における実験 I と II の比較(平 均值, 標準偏差)

Tab. 1 Comparison between Experiment I and II on frequency response (mean, standard deviation).

\begin{tabular}{c|c|c}
\hline & Ex. I & Ex. II \\
\hline $\mathrm{f}(\mathrm{Hz})$ & \multicolumn{2}{|c}{ Gain $(\mathrm{dB})$} \\
\hline 0.1 & $-0.0444 \pm 0.0430$ & $-0.172 \pm 0.00146$ \\
\hline 0.2 & $-0.143 \pm 0.143$ & $-0.804 \pm 0.00450$ \\
\hline 0.3 & $-0.569 \pm 0.531$ & $-2.15 \pm 0.0298$ \\
\hline 0.4 & $-0.818 \pm 0.999$ & $-3.03 \pm 0.0541$ \\
\hline 0.5 & $-2.13 \pm 1.71$ & $-4.29 \pm 0.122$ \\
\hline $\mathrm{f}(\mathrm{Hz})$ & \multicolumn{2}{|c}{ Phase (deg) } \\
\hline 0.1 & $-28.1 \pm 4.59$ & $-17.6 \pm 0.0151$ \\
\hline 0.2 & $-57.6 \pm 9.49$ & $-36.0 \pm 0.0220$ \\
\hline 0.3 & $-85.9 \pm 14.1$ & $-50.9 \pm 0.0903$ \\
\hline 0.4 & $-115 \pm 19.0$ & $-64.0 \pm 0.0173$ \\
\hline 0.5 & $-139 \pm 18.8$ & $-72.7 \pm 0.0574$ \\
\hline
\end{tabular}

実験IIIにおても，時間領域のみの検討ではあるが， 図 8 に示すように $\mathrm{y}_{\mathrm{p}}$ と $\mathrm{y}_{\mathrm{m}}$ の両者はよく一致すること が明らかになった。これより, 式(25)を満足しない目標 值に対しても, 本 MFMTCS は有効であると推察され た。

以上の結果より, 本研究で提案した MFMTCS は操 作者による制御量の差異を低減し，その制御結果も所 望の規範モデルの特性と一致することを実験的に確か めることができ，当初の目的は達成されたものと考え る.

しかし，予備実験の段階で二次形式評価関数の重み 行列 $\mathrm{Q}_{1}$ の值の大きさにより操作性が著しく劣化する

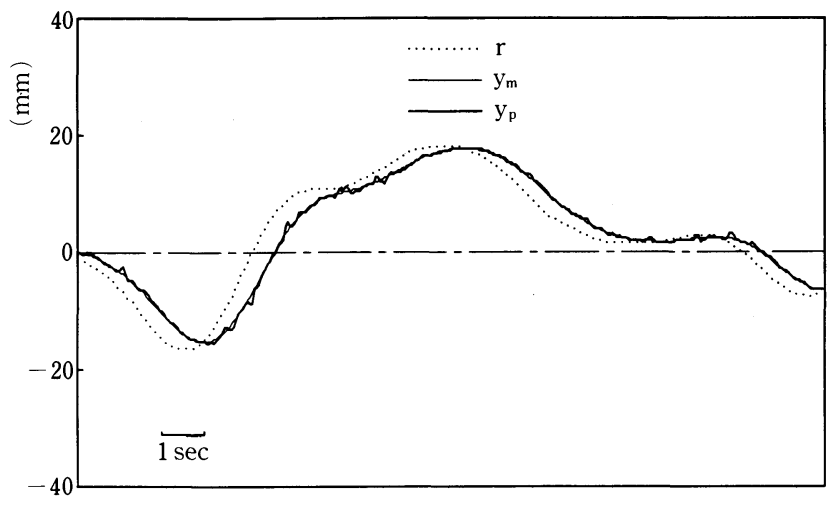

図 8 規範モデルと実験結果の比較（実験III， 被験者 M-1, 試行 10 回目)

Fig. 8 Comparison between reference model and experimental result (Ex. III, Sub. M-1, 10th trial). 
ことが明らかになった，すなわち，上述のむだ時間の 補償とも関連するが， $Q_{1}$ の值を大きくするほど $\mathrm{y}_{\mathrm{p}}$ と $\mathrm{y}_{\mathrm{m}}$ は非常によく一致するものの, 操作者の操作以前 (むだ時間内)に明らかに知覚できる $\mathrm{y}_{\mathrm{p}}$ が生じたり,ま た指, 手首の感覚から得られる操作量と $\mathrm{y}_{\mathrm{p}}$ との関連が 薄れるなどの操作性に問題が生じることが明らかにな った。

これは, 図 2 に示すように本 MFMTCSでは構造上 操作者が介在しない場合, あるいは介在しても操作が 行われていない状態でも，r が規範モデルに入力され ると $\mathrm{u}_{\mathrm{c}}$ が生じ, $\mathrm{y}_{\mathrm{p}}$ を $\mathrm{y}_{\mathrm{m}}$ に追従させる制御が行われる ためである。ここで，このような機能は操作者に不測 の事態が生じた場合の支援機能とみなすこともできる が，逆に操作者不在でも制御可能であれば，手動制御 の意義もなく，自動化すればよいとも考えることがで きる.

そこで, 簡単なシミュレーションを行い, 操作者の 操作が系にどのように関与しているのかを検討した.

シミュレーションは，人間モデルを

$$
\mathrm{A}_{\mathrm{h}}=\left[\begin{array}{rr}
0.40 & 1 \\
-0.03 & 0
\end{array}\right], \mathrm{B}_{\mathrm{h}}=\left[\begin{array}{r}
0.90 \\
-0.36
\end{array}\right]
$$

と設定し，プラント，規範モデルおよびその他の条件

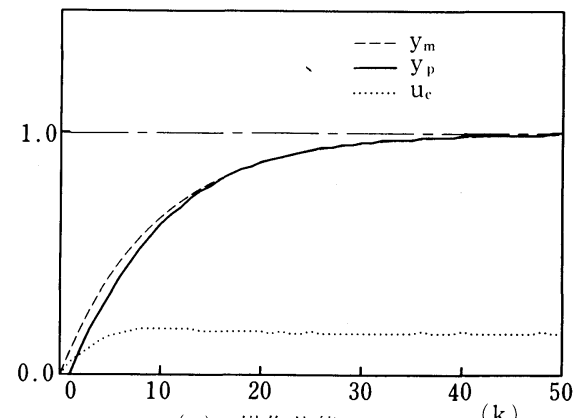

(a) 操作:状態

(a) Operating state

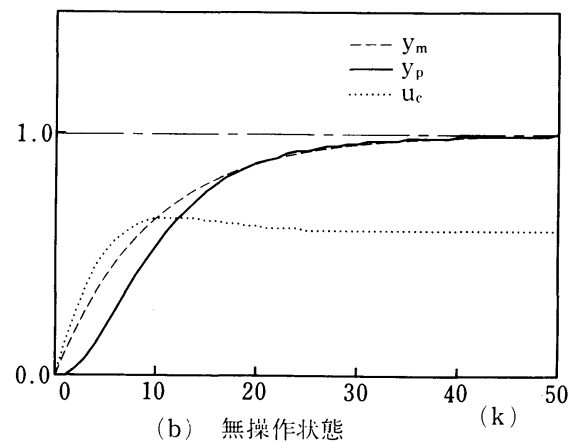

(b) Non-operating state

図 9 MFMTCSのシミュレーション

Fig. 9 Simulation of MFMTCS.
は実験II と同じとした。また，r はステップ入力とし た.

この結果と人間モデルの状態変数, 出力を常に零 (無 操作）状態とした結果との比較を行った。ただし

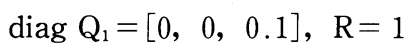

とした.

その結果を図 9 に示す. 図 9 より, 無操作状態にお いても $\mathrm{y}_{\mathrm{p}}$ と $\mathrm{y}_{\mathrm{m}}$ の定常偏差はなくなるが, 操作状態に 比べ, 過渡状態での追従誤差は大きくなり, また制御 入力 $\mathrm{u}_{\mathrm{c}}$ も大きくなることが明らかになった。すなわ ち, これらより推察して, 操作者は過渡状態における $\mathrm{y}_{\mathrm{m}}$ に対する $\mathrm{y}_{\mathrm{P}}$ の追従性能を向上させ,さらに $\mathrm{u}_{\mathrm{c}}$ に対 する制御エネルギを低減させる役目を担っていると考 えることができる。

したがって, 本 MFMTCSにおける操作者による操 作の意義は存在し，また本 MFMTCS を上述のように 操作者および系全体の安全性などに対する支援機能を 有するシステムであるととらえることができると考え る.

\section{5. むすび}

先報における問題の改善を図り，個人差が及ぼす影 響の低減をめざした手動制御系をモデル追従サーボ系 設計手法をもとに構成し，その有効性を実験的に示し た. 本研究ではプラントは 2 入力系としたが, $\mathrm{B}_{\mathrm{p}}$ の各 列ベクトルを同じ值にすれば 1 入力系として扱える. ただし,この場合プラント入力は $\mathrm{y}_{\mathrm{h}}$ と $\mathrm{u}_{\mathrm{c}}$ を加算したも のとなる。

しかし，本制御系は操作者が無操作状態でも制御量 はモデル出力に追従する特性を有し, さらにプラント と規範モデルの両出力の一致の精度と操作性とは相反 する関係にある。これらのことから，本制御系は操作 者の機械への関わりを少なくすることによって,さら にまた操作性を害することによって，個人間の差異を 低隇していると解釈され，人間工学的な観点から問題 があるという指摘もある。事実，この指摘どおりでは あるが，しかしこれらの問題は，すべて二次形式評価 関数の重み行列の值に依存している.すなわち，これ らの問題に対処するためには, 重み行列により, 上述 の両出力の一致の精度と操作性，もしくは機械への関 わりのトレードオフをうまくバランスさせる必要があ る. 本研究では, 本制御系により, 特に先報における 制御系の問題点が改善され，そして操作者による制御 量の差異が低減されるか否かを実験的に確かめること を第一の目的としたため, 上述のバランスも考慮した うえで，試行錯誤的ではあるが，大きめの重み行列を 
採用した。その結果, 当初の目的は達成された。した がって, 本制御系における操作者の制御特性などの解 析から, 重み行列の值を操作者の操作に対する感性な どにより，また操作状況に応じて実時間で設定できる ようなアルゴリズムが構築され，上述のようなトレー ドオフがうまくバランスさせられれば，これらに対す る改善が図れると考えられる。しかし，現在のところ 具体的な方策はない.

また，本システムを系の安全性，安定性に対する支 援機能を有するものととらえれば，制御入力 $\mathrm{u}_{\mathrm{c}}$ を常時 プラントに付加する必要はなく，操作者に不測の事態 が生じた場合, また操作量により安全性が阻害される 危険性が予測された場合に, $\mathrm{u}_{\mathrm{c}}$ を付加し，より安全な制 御量となるようにすることも可能であると考えられる. しかし, 本研究では, これらについての検討までには
至っておらず, 実用上の点からも検討課題が残されて いる.

最後に，実験やデー夕解析にご協力いただいた当時 大学院生の辻 泰志君に心から感謝いたします。

なお, 本研究は平成 2 年度文部省科学研究費の補助 を受けたものであることを付記する。

\section{参考文献}

1) 末長 修, 井原素三: 個人差が人間-機械系に 及ぼす影響の低減について, 人間工学, $26(2)$, 75〜80, 1990.

2）古田勝久：ディジタルコントロール，186～192, コロナ社, 東京, 1989 .

3）岩井善太, 井上 昭, 川路茂保：オブザーバ, 198〜204，コロナ社，東京，1988. 